\title{
Experimental assessment of antidiarrheal and antisecretory activity of $80 \%$ methanolic leaf extract of Zehneria scabra in mice
}

\author{
Wondmagegn Tamiru Tadesse ${ }^{*}$, Abebe Ejigu Hailu', Abyot Endale Gurmu² and Abraham Fikru Mechesso ${ }^{3}$
}

\begin{abstract}
Background: The leaf of Zehneria scabra is traditionally used for the management of diarrhea in Ethiopia. Its use, however, has not been scientifically validated for safety and efficacy. The aim of this study was to investigate antidiarrheal and antisecretory effects of hydroalcolic leaf extract of $Z$. scabra in mice models.

Methods: For each of antidiarrheal, gastrointestinal motility and antisecretory activity study Swiss albino mice were divided in to five groups. Group I was treated as control group and received $10 \mathrm{ml} / \mathrm{kg}$ of 2\% Tween-80 orally; Group II served as a positive control and took standard drug in each of the experiments orally; Group III, IV and V were test groups which received the methanolic extract orally at 100, 200 and $400 \mathrm{mg} / \mathrm{kg}$, respectively. Depending on the model total weight of fecal output, total weight of wet feces, total number of fecal output, number of wet faeces, length of intestinal transit and intestinal weight were collected. Finally, data were analyzed using one-way ANOVA followed by Tukey's post test.
\end{abstract}

Result: In castor oil induced diarrhea model, the extract dose produced a significant reduction in mean stool score $(1.94 \pm 0.102)$ at $200 \mathrm{mg} / \mathrm{kg}$. Moreover, the 100, 200, and $400 \mathrm{mg} / \mathrm{kg}$ doses inhibited stool frequency by 40,45 and $55 \%$, respectively. All test doses of extract and loperamide $(3 \mathrm{mg} / \mathrm{kg})$ reduced fecal fluid content significantly $(p<0.01)$. The $100 \mathrm{mg} / \mathrm{kg}$ dose of extract produced $25.74 \%$ reduction of fluid content $(p<0.001)$ while both 200 and $400 \mathrm{mg} / \mathrm{kg}$ showed $29.70 \%(\mathrm{p}<0.001)$ compared to negative control group.

Conclusion: The extract of Zehineria scabra showed antidiarrheal and antisecretory activity in mice model. Moreover, the extract found to be safe at dose of $2000 \mathrm{mg} / \mathrm{kg}$ in mice model. The findings suggest the validity of the acclaimed effect of Zehineria scabra as antidiarrheal agent in Ethiopian traditional herbal medicine.

Keywords: Anti-diarrhea, Zehneria scabra, Anti-secretory, Rodents

\section{Background}

Diarrhea is the passage of abnormal liquid or unformed stool at an increased frequency. Infectious agents, certain medications, plant and animal toxins, gastro-intestinal disorders, and substances that increase gastrointestinal tract secretions may cause it. It can also be caused by the ingestion of poorly absorbable materials, or inflammatory and dysmotility problems of the gastro-intestinal tract [1-3].

Diarrheal diseases are one of the leading causes of morbidity and mortality in developing countries and are

\footnotetext{
* Correspondence: mail2wondm@gmail.com

'Department of Pharmacology and Clinical Pharmacy, School of Pharmacy,

Addis Ababa University, Addis Ababa, Ethiopia

Full list of author information is available at the end of the article
}

responsible for the death of millions of people each year. There are a number of epidemiological and experimental evidences worldwide related to acute diarrheal disease, which is one of the principal causes of death in the infants [4]. Around 2.5 million children die each year worldwide and $80 \%$ of which are reported in developing countries. Diarrhea is most common in crowded living conditions coupled with poor hygiene and malnutrition [5].

Although currently used drugs are important in the management of diarrhea, they still are linked with adverse effects and contraindications. For instance, racecadotril and loperamide are used to treat secretary diarrhea but they produce bronchospasm, vomiting and fever. Moreover, some are contraindicated in children below 6 years 
of age (loperamide) and intestinal obstruction. Different antibiotics used do have valuable importance to fight this condition; however, drug resistance is another issue to think about [6].

Despite immense technological advancement in modern medicine, many people in the developing countries still rely on healing practices and medicinal plants for their health care needs. Moreover, to combat the problem of diarrhea in developing countries, the World health organization (WHO) has constituted diarrhea control program aimed at a holistic approach to include all aspects of traditional medical practices, evaluation of health education and preventive approaches [7]. A range of medicinal plants with antidiarrheal properties has been widely used by the traditional healers; however, the effectiveness of many of these anti-diarrheal traditional medicines has not been scientifically evaluated [8].

Traditional medicine practice has been documented in Ethiopia for treatment of various ailments. Including diarrhea for which by various plants has been used. Zehneria scabra (Linn.f.) Sond. (Cucurbitacea) (vernacular name - 'hareg ressa') is one of the commonly used medicinal plants in Ethiopian traditional medicine practices. Being a climbing or trailing herb, it can go up to $10 \mathrm{~m}$ in length. Stems become woody with corky-ridged bark as they grow old. And it has ovate, broadly ovate or pentagonal leaves. Traditionally in Ethiopia the flowers of the plant has reportedly been used for topical treatment of alopecia, wound and eczema along with other herbals mixed together [9]. Additionally, the leaves [10], fruit, and flower have been used for the treatment of abdominal colic in decoction of water and taken orally [11]. The traditional use of the leaves of this plant for the treatment of diarrhea is also reported in rural central Ethiopia and Burundi besides its use for skin reaction [11]. Scientific works to testify to any of the claims are almost non-existent except a few studies that conducted antimicrobial activity test for the various extracts of the dried, powdered leaves of Z. scabra. The results were promising with the aqueous and methanolic extracts exhibiting interesting inhibitory activity against $S$. aureus, P. aeruginosa, E. coli and C. albicans [12,13]. Related to phytochemical studies, NMR analysis of the ethyl acetate root extract of the plant reported the presence of gypenoside group, like many other Cucurbitacea family members [14].

It is necessary to establish scientific evidences for therapeutic use of such traditional medicinal plants, as it may potentially be useful source of new effective therapies in drug development process. Hence, this study aimed at evaluating the traditional claim of antidiarrheal and antisecretory effect of methanolic leaf extract of Zehneria scabra and its acute toxicity in mice model.

\section{Method}

\section{Drugs and chemicals}

Methanol (RANKEM, India), Tween-80 (Sigma-Aldrich, UK), Activated Charcoal (Lab. Reagent, India), Castor Oil and loperamide were obtained from a local retail outlet in Addis Ababa. Atropine Sulfate (AdvaCare, USA), Hydrochloric Acid (BDH Ltd, England) Chloroform (ACS, Merck), Sulfuric Acid (Farm Italia Carrloerba, Italy), Ammonia (Merck Millipore, India), Acetic Anhydride (Techno Pharmchem, India), Ferric Chloride (Fisher, USA), Potassium Ferrocyanide (BDH Ltd, England), Lead Acetate (BDH Ltd, England), and Ethyl Acetate (ACS, Merck).

\section{Plant material}

The leaves of Zehneria scabra were collected from Debre Tabor and surrounding area. Taxonomic identifications were then established by the Department of Biology, National Herbarium, Addis Ababa University. A voucher specimen was also kept there (Voucher sample number WT/03).

\section{Experimental animals}

Healthy male Swiss albino mice, weighing between 20$30 \mathrm{~g}$, were obtained from animal house of Pharmacology department, University of Gondar. The animals were housed in a polyethylene glycol cage (5 to 8 animals per cage) and acclimatized, for a minimum of 5 days prior to pharmacological studies. The animals were maintained under standard condition of relative humidity (44-56\%), temperature $\left(25 \pm 2^{\circ} \mathrm{C}\right)$ and $12 / 12 \mathrm{~h}$ light-dark cycle $[15,16]$ and allowed free access to pellets and tap water.

\section{Extraction procedure}

The leaves of Zehneria scabra were collected and thoroughly washed with distilled water to remove dirt and soil. The plant material was air-dried at room temperature and pulverized into a dry powder. Then, $100 \mathrm{~g}$ of this material was macerated with $500 \mathrm{ml}$ initially and then the residue was macerated with $400 \mathrm{ml}$ and $300 \mathrm{ml}$ of $80 \%$ methanol, successively. The respective extract was filtered using gauze and Whatman No-1 filter paper, and dried under reduced pressure, at temperature below $45^{\circ} \mathrm{C}$ in oven. The percentage yield of the process was $17.5 \%(\mathrm{w} / \mathrm{w})$. The extract material was kept in an air-tight container and stored at $4^{\circ} \mathrm{C}$ until needed. The extract was semisolid at room temperature and solidified at storage in a refrigerator. When re-exposed to room temperature, however, the extract turned in to semisolid.

\section{Preliminary phytochemical screening test}

The crude extract was screened for the presence or absence of secondary metabolites such as alkaloids, steroidal compounds, phenolic compounds, saponins, tannins and 
anthraquinones using standard procedures by coloring and precipitation assays using standard procedures as described elsewhere $[17,18]$.

\section{Acute toxicity test}

Acute toxicity test was done based on the limit test recommendations of OECD 425 Guideline [16]. First, female Swiss albino mouse was fasted for $4 \mathrm{~h}$ and then loaded with $2000 \mathrm{mg} / \mathrm{kg}$ of the extract, orally. The mouse was then observed for physical or behavioral changes within $24 \mathrm{~h}$ strictly, with special attention during the first $4 \mathrm{~h}$. Based on the results found from the first mouse, other four female mice were recruited and fasted for 4 $\mathrm{h}$. Then, the animals were administered a single dose of $2000 \mathrm{mg} / \mathrm{kg}$ followed by similar strict observation. Such observation was continued for further 14 days for any signs of toxicity.

\section{Grouping and dosing of animals}

The animals were randomly assigned to different groupsas negative control group, treatment groups for different doses of extracts of Zehneria scabra, and positive control group. Group I was negative control and was given a vehicle, (2\% (v/v) Tween-80 in water). Group II (positive control group) was given standard drug, loperamide (3 $\mathrm{mg} / \mathrm{kg}$, orally) in both castor oil induced antidiahreal test and misoprostol induced antisecretory test and atropine sulfate $(0.1 \mathrm{mg} / \mathrm{kg}$, i.p.) for gastrointestinal motility test by charcoal meal. Group III to V (test groups) were given the extract of Zehneria scabra at doses of 100 (ZS100), 200 (ZS200) and $400($ ZS400) $\mathrm{mg} / \mathrm{kg}$, respectively. Plant extracts and the standard drug, loperamide were dissolved with distilled water, were administered orally and volume administered was $10 \mathrm{ml} / \mathrm{kg}$ for all animals.

As per OECD [16] guideline, after the safety evaluation of the plant, $1 / 10^{\text {th }}$ of the maximum dose $(2000 \mathrm{mg} / \mathrm{kg})$ was considered as a middle dose, half and double of the middle dose were taken as the low and the high doses, respectively. The test doses were prepared freshly on the day of the experiment. Animals were treated with vehicle or treatment $1 \mathrm{~h}$ before subjecting to the different tests.

\section{Anti-diarrhea activity tests}

\section{Antidiarrhea activity on Castor oil-induced diarrhea}

The method described by Franca 2008 [19] was followed for this study. The animals were screened initially by giving $0.5 \mathrm{ml}$ of castor oil and only those showing diarrhea were selected for the final experiment. Each animal was placed in individual cage, the floor of which was lined with blotting paper and every hour the floor lining was changed. Diarrhea was induced by oral administration of $0.5 \mathrm{ml}$ castor oil to each mouse, $30 \mathrm{~min}$ before the above treatments. Every hour, total weight of faecal output, total weight of wet faeces, total number of faecal output, and number of wet faeces were recorded. A numerical score based on stool consistency was assigned as follows: normal stool $=1$, semi-solid stool $=2$ and watery stool $=$ 3 [20]. And \% inhibition of diarrhea was calculated as follows:

$$
\begin{gathered}
\text { Mean Number of wet } \\
\text { of diarrhea }
\end{gathered}=\frac{\begin{array}{c}
\text { Mefecation }(\text { control }- \text { test }) \\
\text { Mean wet defecation of control }
\end{array} \times 100}{\text { dibition }}
$$

The in vivo antidiarrheal index (ADI in vivo) was then expressed according to the formula [21]:

$$
\mathrm{AD} I_{\text {in vivo }}=\sqrt[3]{\left(D_{D T} \times G_{M T} \times N_{F S}\right)}
$$

Where $\mathrm{D}_{\mathrm{DT}}$ is the delay in defecation time or diarrheal onset (as \% of control), $\mathrm{G}_{\mathrm{MT}}$ is the Gasrointesitinal motility by charcoal travel reduction (as \% of control), and $\mathrm{N}_{\mathrm{FS}}$ is the reduction in the number (frequency) of stools (as \% of control).

\section{Gastrointestinal motility test by charcoal meal}

After the grouping, each animal was loaded with $1 \mathrm{ml}$ of charcoal meal (3\% deactivated charcoal in normal saline) orally. After $30 \mathrm{~min}$ of respective treatment of each group, the animals were sacrificed and the movement of charcoal from pylorus to cecum was measured. The charcoal movement was expressed in terms of percentage [22]. The percentage of inhibition of gastrointestinal motility was determined by using the following equation:

$$
\% \text { inhibition of intestinal }=\frac{\text { test extract }- \text { control }}{\text { control }} \times 100
$$

\section{Antisecretory assay}

The effect of the hydroalcoholic extract on fluid secretion in intestine, which was induced by misoprostol at $20 \mu \mathrm{g} / \mathrm{kg}$, was studied using mouse model. Mice were fasted for $24 \mathrm{~h}$ before induction by misoprostol. $1 \mathrm{~h}$ later each group was then treated just as stated above in the grouping and dosing of animals. Mice were then sacrificed after $24 \mathrm{~h}$ and fluid accumulation ratio (the weight of intestine to the rest of the body weight of mouse) was recorded and the antisecretory activity was expressed in percentage of inhibition [23].

$$
\begin{aligned}
& \text { \% Inhibition of intestinal fluid accumulation ratio } \\
& =\frac{\text { Ratio of test drug }- \text { Ratio of control }}{\text { Ratio of Control }} \times 100
\end{aligned}
$$

In addition to this, the weight of wet stool and dry stool (after $24 \mathrm{hr}$ of defecation) were used to calculate the fluid content in the stool and the difference between wet stool and dry stool was recorded as stool fluid content. 


\section{Statistical analysis}

All data were expressed in appropriate data presentation methods. Statistical analysis was carried out using one way ANOVA followed by Tukey's post hoc tests. The results were considered significant at p-value less than 0.05 . For data processing and analysis SPSS statistical software Version 20.0 was used.

\section{Ethical clearance}

All procedures were complied with The Guide for the Care and Use of Laboratory Animals [15] and OECDguideline-425 for acute toxicity [16]. The procedures were approved by the Institutional Review Board of the college of medical and health sciences, University of Gondar and ethical clearance was obtained from the research and publication office of the University (Ref. No. CMHS-RPO/045/2013).

\section{Results}

\section{Preliminary phytochemical screening}

The leaves of $Z$. scabra crude extract revealed the presence of various secondary metabolites based on preliminary phytochemical screening test (Table 1). Among the detected in the crude extract were tannins, saponins, anthraquinones, O-anthraquinones and phenols. On the other hand, alkaloids and steroidal compounds were not detected.

\section{Acute toxicity test}

None of the animals showed behavioral, neurological or physical changes characterized by symptoms such as reduced motor activity, restlessness, convulsions, coma, diarrhea and lacrimation at the limit dose of $2000 \mathrm{mg} / \mathrm{kg}$ of the hydroalcoholic extract of $Z$. scabra during the observation period. In addition, no mortality was observed at the test dose. Thus, the median lethal dose (LD50) of the plant extract was found to be greater than $2000 \mathrm{mg} / \mathrm{kg}$.

Table 1 Phytochemical screening results of $\mathbf{8 0} \%$ methanolic extract of leaves of Zehneria scabra

\begin{tabular}{lc}
\hline Test & Result \\
\hline Alkaloids & - \\
Tannins & + \\
Saponins & + \\
Anthraquinon glycosides & + \\
O-anthraquinones & + \\
Phlabotanins & + \\
Steroidal compounds & - \\
Phenolic compounds & + \\
\hline
\end{tabular}

+: present, -: absent.
The effect of Z. scabra extract on castor oil-induced diarrhea in mice

The effect of the extract on the mean stool score and number of wet feces is shown in Table 2. After $30 \mathrm{~min}$ of the administration of castor oil, all the animals of the negative control group ( $2 \% \mathrm{TW}-80$ treated) were apparently diarrheic with a mean stool score of $2.68 \pm 0.05$ out of 3 scale stool score. Z. scabra extract at doses 100 $\mathrm{mg} / \mathrm{kg}(\mathrm{p}<0.05), 200 \mathrm{mg} / \mathrm{kg}(\mathrm{p}<0.001)$ and $400 \mathrm{mg} / \mathrm{kg}$ $(\mathrm{p}<0.01)$ significantly reduced the mean stool score and the number of wet feces $(\mathrm{p}<0.001$ for all doses) compared to the negative control. Whilst loperamide significantly decreased mean stool score and number of wet feces compared to controls $(\mathrm{p}<0.001)$, no statistically significant difference was noted when compared with the other doses of the extract. It is of note that maximum reduction was achieved still with loperamide (84.5\%).

Moreover, treatment with Z.scabra produced a similar pattern of change in number of defecation as depicted in Table 3. Accordingly, a significant reduction in the number of defecations over four hours and the total number of defecation was observed with all the test doses of the extract compared with the vehicle treated group. All test doses demonstrated significant reduction in number of defecation starting from the $2^{\text {nd }}$ hour through the fourth hour with percent inhibition of defecation 40, 45 and 55\% for 100,200 , and $400 \mathrm{mg} / \mathrm{kg}$ doses, respectively. However, no apparent change was noted among the different doses of the extract. The standard drug also showed a marked reduction in number of defecation by about $65 \%$ compared to vehicle treated group, which was by far the highest of all. However, once again no detectable changes were noted when compared to all doses of the extract.

Stool fluid content is calculated as the difference of the weight of wet stool (fresh) to that of the dried (measured after $24 \mathrm{~h}$ of defecation). As demonstrated in the Table 4, treatment with $100 \mathrm{mg} / \mathrm{kg}$ and $200 \mathrm{mg} / \mathrm{kg}$ of the extract did not produce significant decrease in stool fluid content in the $1 \mathrm{~h}, 2 \mathrm{~h}$ and $4 \mathrm{~h}$ compared to negative control. By contrast, $400 \mathrm{mg} / \mathrm{kg}$ of the extract did show significant reduction $(\mathrm{p}<0.05)$ in the stool fluid content by $0.05 \pm 0.02$ at $2 \mathrm{~h}$. At the $3 \mathrm{~h}$, all doses of the extract and the positive control loperamide $(3 \mathrm{mg} / \mathrm{kg}$ ) treated groups demonstrated a significant difference of fluid content with $0.00 \pm 0.00(\mathrm{p}<0.001), 0.09 \pm 0.03$ $(\mathrm{p}<0.01), 0.04 \pm 0.02(\mathrm{p}<0.001)$ and $0.05 \pm 0.02 \mathrm{~g}$ $(\mathrm{p}<0.001)$ compared to that of $0.29 \pm 0.08 \mathrm{~g}$ of the negative control group. However, there was no significant difference in stool fluid content at the $4 \mathrm{~h}$ among the groups.

The effect of $Z$. scabra extract on interstitial motility in mice The effect of $Z$. scabra extract on the intestinal transit is depicted in Table 5. All doses of the extract failed to produce significant alteration in the \% intestinal motility 
Table 2 The effect of $Z$. scabra extract on stool score scale in castor oil- induced diarrhea in mice

\begin{tabular}{lllll}
\hline Group & Onset of diarrhea & Mean stool score & Number of wet feces & \% Inhibition of diarrhea \\
\hline 2\%TW-80 & $66.4 \pm 3.06$ & $2.68 \pm 0.05^{\text {a }}$ & $19.4 \pm 2.44^{\text {a }}$ & - \\
Lop3 & $180.5 \pm 15.45$ & $1.49 \pm 0.093^{* * *}$ & $3 \pm 0.89^{* * *}$ & 84.5 \\
ZS100 & $100.33 \pm 8.41$ & $2.34 \pm 0.098^{* a}$ & $9.3 \pm 1.20^{* * * b}$ & 52.1 \\
ZS200 & $118.33 \pm 7.34$ & $1.94 \pm 0.102^{* * \mathrm{~b}}$ & $7 \pm 0.85^{* * *}$ & 63.9 \\
ZS400 & $140.00 \pm 16.48$ & $2.26 \pm 0.119^{* * a}$ & $6.5 \pm 0.81^{* * *}$ & 66.5
\end{tabular}

Values are mean \pm S.E $(n=5){ }^{* * *} p<0.001$ values compared with the negative control; ${ }^{* *} p<0.01$ values compared with the negative control, ${ }^{*} p<0.05$ values compared with the negative control. ${ }^{\mathrm{a}} \mathrm{p}<0.001$ values compared with the positive control; ${ }^{\mathrm{b}} \mathrm{p}<0.01$ values compared with the positive control.

compared to the negative control. The negative control (2\% Tween-80 solution) resulted in $90.6 \pm 9.2 \%$ intestinal motility by the marker-charcoal meal. The 100, 200 and $400 \mathrm{mg} / \mathrm{kg}$ oral dose of the extract exhibited $86.9 \pm 8.4$, $86.1 \pm 5.9 \%$ and $78.0 \pm 9.4 \%$ intestinal motility, respectively (Table 5). However, the standard drug, atropine demonstrated a significant inhibition in intestinal motility.

\section{The effect of $Z$. scabra extract on intestinal fluid secretion} by weight ratio

As demonstrated in Table 6, all test doses of the extract significantly reduced the intestinal weight ratio in dose dependent manner. The $100 \mathrm{mg} / \mathrm{kg}$ oral dose of the extract produced $25.74 \%$ inhibition of weight of intestinal content $(\mathrm{p}<0.001)$ relative to $2 \% \mathrm{TW}-80$ treated negative control group. Moreover, both the 200 and $400 \mathrm{mg} / \mathrm{kg}$ treated groups showed $29.70 \%$ inhibition of intestinal weight ratio $(\mathrm{p}<0.001)$ relative to the negative control group. In comparison to loperamide $(3 \mathrm{mg} / \mathrm{kg})$ treated group, all tested doses of the extract depicted superior percentage of reduction in weight of intestinal ratio.

\section{In vivo antidiarraheal index}

Results for the in vivo antidiarheal index were 17.33, 21.31 and 34.25 at the dose of 100,200 and $400 \mathrm{mg} / \mathrm{kg}$ oral doses of the plant extract, while loperamide gave a maximum index of 74.33 .

\section{Discussion}

Several studies have validated the use of antidiarrheal medicinal plants by investigating the biological activity of extracts of such plants, which have antispasmodic effects, delay intestinal transit, suppress gut motility, stimulate water adsorption, or reduce the intraluminal fluid accumulation [23]. The leaves of Z. scabra have been used for its antidiahreal effect in Ethiopian folk medicine without any scientific validation for its safety and efficacy [24,25]. However, it is evidenced to have antimicrobial activity against E.coli, S.auerus, P.aueroginosa and C. albicans [12,13]. The present study was conducted to validate antidiarrheal efficacy of Z. scabra extract in the different experimental models of diarrhea. In the present study the methanolic extract of Z. scabra have showed antidiarrheal activity in different animal models.

Despite the multiplicity of etiologies of diarrhea, literatures state that there are four major pathophysiologies that lead to diarrhea. These include increased luminal osmolarity (osmotic diarrhea), increased electrolytes secretion (secretory diarrhea), decreased electrolytes absorption, and deranged intestinal motility causing a decreased transit time [26]. As an intervention of diarrhea, many antidiarrheal agents elicit effects by reducing the gastrointestinal motility and/or the secretions [23].

In contrast, laxatives and diarrhea causing agents enhance gastrointestinal motility and/or secretions. For instance, castor oil; which is used as an inducer of diarrhea in this study, is known for its laxative effects because of the active principle, retinoic acid. The active principle of castor oil is known to change the electrolyte permeability of the intestinal membrane and through elevated prostaglandin biosynthesis and release it causes diarrhea similar

Table 3 The effect of $Z$. scabra extract frequency of defecation on castor oil-induced diarrhea within four hours in mice

\begin{tabular}{|c|c|c|c|c|c|c|}
\hline \multirow[t]{2}{*}{ Group } & \multicolumn{4}{|c|}{ Number of deifications in specific time } & \multirow{2}{*}{$\begin{array}{l}\text { Total number } \\
\text { of defecation }\end{array}$} & \multirow{2}{*}{$\begin{array}{l}\text { Inhibition } \\
(\%)\end{array}$} \\
\hline & $1 \mathrm{hr}$ & $2 \mathrm{hr}$ & $3 \mathrm{hr}$ & $4 \mathrm{hr}$ & & \\
\hline $2 \%$ TW-80 & $4.6 \pm 2.86$ & $9.4 \pm 1.12^{\mathrm{a}}$ & $4.2 \pm 0.8^{\mathrm{a}}$ & $1.8 \pm 0.49^{b}$ & $20 \pm 2.43^{a}$ & - \\
\hline Lop3 & $5.2 \pm 1.14$ & $1.8 \pm 0.70^{* * *}$ & $0 \pm 0.00^{* * *}$ & $0 \pm 0.00^{*}$ & $7 \pm 1.57^{* * *}$ & 65 \\
\hline ZS100 & $4.5 \pm 0.72$ & $4.2 \pm 1.01 * *$ & $2 \pm 0.37^{* b}$ & $1.5 \pm 0.56^{b}$ & $12 \pm 0.95^{* *}$ & 40 \\
\hline ZS200 & $6.3 \pm 0.615$ & $2.7 \pm 0.42^{* * *}$ & $1.7 \pm 0.50^{* *}$ & $1 \pm 0.31$ & $11 \pm 0.43^{* *}$ & 45 \\
\hline ZS400 & $5.7 \pm 1.33$ & $1.7 \pm 0.21^{* * *}$ & $1.2 \pm 0.40^{* *}$ & $0.5 \pm 0.22$ & $9 \pm 1.53^{* * *}$ & 55 \\
\hline
\end{tabular}

Values are mean number of defecations $\pm S . E(n=5),{ }^{*} \mathrm{p}<0.05$ compared with the negative control, ${ }^{* *} \mathrm{p}<0.01$ compared with the negative control, ${ }^{* * *} \mathrm{p}<0.001$ compared with the negative control. ${ }^{a} p<0.001$ values compared with the positive control; ${ }^{b} p<0.01$ values compared with the positive control. 
Table 4 The effect of $Z$. scabra on weight composition of wet and dried stool in castor induced-diarrhea in mice

\begin{tabular}{lllll}
\hline Group & \multicolumn{3}{c}{ Stool fluid content in Weight (g) } \\
\cline { 2 - 5 } & $\mathbf{1 h r}$ & $\mathbf{2 h r}$ & $\mathbf{3 h r}$ & $\mathbf{4 h r}$ \\
\hline 2\%TW-80 & $0.18 \pm 0.12$ & $0.50 \pm 0.04$ & $0.29 \pm 0.08)^{\mathrm{a}}$ & $0.04 \pm 0.03$ \\
Lop3 & $0.07 \pm 0.09$ & $0.36 \pm 0.18$ & $0.00 \pm 0.00^{* * *}$ & $0.01 \pm 0.01$ \\
ZS100 & $0.26 \pm 0.10$ & $0.28 \pm 0.05$ & $0.09 \pm 0.03^{* *}$ & $0.04 \pm 0.02$ \\
ZS200 & $0.40 \pm 0.09$ & $0.18 \pm 0.07$ & $0.04 \pm 0.02^{* * *}$ & $0.07 \pm 0.04$ \\
ZS400 & $0.42 \pm 0.11$ & $0.05 \pm 0.02^{*}$ & $0.05 \pm 0.02^{* * *}$ & $0.01 \pm 0.01$ \\
\hline
\end{tabular}

Values are mean weight of stool \pm S.E. $(n=5),{ }^{*} p<0.05$ compared with the negative control, ${ }^{* *} p<0.01$ compared with the negative control, ${ }^{* * *} p<0.001$ compared with the negative control. ${ }^{a} p<0.001$ values compared with the postive control.

to pathophysiologic conditions that cause diarrhea $[27,28]$. Because of this, castor oil was used to induce diarrhea in the experimental animals of this study. Different researches have shown that castor oil causes diarrhea 1-2 $\mathrm{h}$ just after administration of 0.1-0.3 $\mathrm{ml}$ for mice [29]. In our experiment diarrhea response was seen within $1 \mathrm{~h}$ in most of the experimental subjects because of the high dose of castor oil $(0.5 \mathrm{ml} /$ mice). Only those mice that showed the diarrheal response were selected for the experiment, to evaluate the effects of $Z$. scabra leaf extract.

The hydroalcolic extract of $Z$. scabra (100-400 mg/kg, p.o.) significantly $(\mathrm{p}<0.001)$ reduced the fecal output produced by castor oil at each hour interval and, of course, in the overall $4 \mathrm{~h}$ interval. At doses of $100-400$ $\mathrm{mg} / \mathrm{kg}$ (p.o.), the plant extract significantly $(\mathrm{p}<0.001)$ and dose dependently delayed the onset of diarrhea induced by castor oil when compared with the untreated controls. Z. scabra (200 mg/kg, p.o.) reduced the number of fecal episodes by $45 \%$ while the dose of $400 \mathrm{mg} / \mathrm{kg}$ (p.o.) significantly $(\mathrm{p}<0.001)$ reduced the number of defecation by $55 \%$. However, the percent inhibition by the $100 \mathrm{mg} / \mathrm{kg}$ was lower than the 200 and $400 \mathrm{mg} /$ $\mathrm{kg}$, indicating higher dose of the crude extract do have a much better antidiarrheal effect. This might be because it is a sub-threshold (sub-effective) dose. This implies that a relatively high dose of the extract is needed to produce an antidiarrheal. This is in line with other reports of other species of plants in which extracts of plants shown to exert antidiarrheal effect at higher doses [17].
Similarly, the extract demonstrated a significant reduction of mean stool score that indicated change of stool consistency from watery to solid stool. At the same time, the number of wet defecations decreased pointing that the extract demonstrated antidiarrheal effect. 200 and 400 $\mathrm{mg} / \mathrm{kg}$ doses of the extract were superior in reducing mean stool score and number of wet stools, respectively.

Meanwhile, the standard drug showed a marked reduction in both fecal outputs produced by castor oil and mean stool score by about $65 \%$ and $84 \%$, respectively. This was by far the highest of all treatment doses of the extract. This can be attributed to the fact that loperamide exerts its antidiarrheal activity by different mechanisms like regulating the gastrointestinal tract, slowing down motility in the intestine, reducing colon flow rates and consequently any effect on colonic motility [30].

Clinically, diarrhea may result from disturbed bowel function, in which case there is impaired intestinal absorption, excessive intestinal secretion of water and electrolytes, and rapid bowel transit [31]. The antidiarrheal index (ADI) is a measure of the combined effects of these different components of diarrhea such as defecation frequency and onset of diarrheal stools, as well as intestinal motility. The plant extract produced a dose-dependent antidiarrheal index, although its greatest effect was lower than that produced by loperamide, the positive control.

The mean ratio of the weight of small intestine to rest of the body of mice and stool fluid content were used to determine the antisecretory activity of the extract. Consistent with the findings of castor oil induced antidiarrheal model, both parameters at all doses level of the extract demonstrated significant antisecretory effect of the extract. Therefore, it can be deduced that the extract possessed comparable antisecretory activity to the standard drug. Although the experimental antidiarrheal models are not a complete predictors of clinical effectiveness, the findings of this study clearly indicated the antidiarrheal potentials of the plant extract.

The plant extract demonstrated significant reductions of water contents, frequency of defecation and intestinal fluid accumulation. On the other hand, gastrointestinal motility test indicated its poor antimotility effect. The overall findings show that the extract demonstrated a

Table 5 The effect of $Z$. scabra extract on intestinal transit in mice using charcoal meal as a marker

\begin{tabular}{lllll}
\hline Group & Total length of intestine $(\mathbf{c m})$ & Distance travelled by charcoal $(\mathbf{c m})$ & \% Intestinal transit & \% Inhibition relative to control \\
\hline 2\%TW-80 & $59.2 \pm 1.48)$ & $53.7 \pm 6.41^{\mathrm{a}}$ & $90.6 \pm 9.2^{\mathrm{a}}$ & - \\
Atropine & $57.1 \pm 2.86$ & $0 \pm 0.0$ & $0.0 \pm 0.0$ & 100 \\
ZS100 & $56.6 \pm 5.86$ & $49.1 \pm 6.0^{\mathrm{a}}$ & $86.9 \pm 8.4^{\mathrm{a}}$ & 4.1 \\
ZS200 & $59.9 \pm 4.793$ & $51.6 \pm 2.9^{\mathrm{a}}$ & $86.1 \pm 5.9^{\mathrm{a}}$ & 4.9 \\
ZS400 & $55.8 \pm 6.80$ & $43.8 \pm 9.8^{\mathrm{a}}$ & $78.0 \pm 9.4^{\mathrm{a}}$ & 13.9 \\
\hline
\end{tabular}

Values are mean length of intestine \pm S.E $(n=5) .{ }^{a} p<0.001$ values compared with the positive control. 


\begin{tabular}{|c|c|c|c|}
\hline Group & $\begin{array}{l}\text { Weight of small } \\
\text { intestine }(g)\end{array}$ & $\begin{array}{l}\text { Ratio of small } \\
\text { intestine to the } \\
\text { rest body of mice }\end{array}$ & $\begin{array}{l}\text { Inhibition of } \\
\text { intestinal } \\
\text { content (\%) }\end{array}$ \\
\hline $2 \%$ TW-80 & $2.09 \pm 0.20$ & $0.101 \pm 0.012^{a}$ & - \\
\hline Lop3 & $1.56 \pm 0.28$ & $0.076 \pm 0.006^{*}$ & 24.75 \\
\hline ZS100 & $1.58 \pm 0.26$ & $0.075 \pm 0.006^{*}$ & 25.74 \\
\hline ZS200 & $1.41 \pm 0.19$ & $0.071 \pm 0.004^{*}$ & 29.70 \\
\hline ZS400 & $1.17 \pm 0.37$ & $0.071 \pm 0.009^{*}$ & 29.70 \\
\hline
\end{tabular}

Values are mean \pm S.E $(n=5),{ }^{*} p<0.001$ compared with the negative control. ${ }^{a} p<0.001$ values compared with the positive control.

comparable antidiarrheal and antisecretory effects. Although the specific mechanisms of action of the extract need to be explored, the antidiarrheal effect of the extract could be related to inhibition of secretion, reducing intraluminal fluid accumulation or enhancing water absorption but not delaying motility. It is widely reported that different antidiarrheal agents exert their effect through different mechanisms such as inhibiting secretion, decreasing motility, delaying intestinal transit, reducing intraluminal fluid accumulation or by enhancing water adsorption [20,30,32].

Phytochemical screening of the plant extract revealed the presence of tannins, phlabotanins, saponins, anthraquinone glycosides, O-anthraquinones. Previous studies also reported the presence of tannins, unsaturated sterols/ triterpens and saponins [25]. Different literatures state that components such as tannins, saponins, steroids, terpenes, alkaloids and flavonoids are responsible for antidiarrheal action of different plant extracts through different mechanisms $[33,34]$. From which tannins and flavonoids are suggested to be responsible for antidiarrheal activity by increasing colonic water and electrolyte reabsorption whereas the others are linked with inhibiting intestinal motility. Tannins are best known to decrease the irritability of the bowel thereby reducing peristaltic index [35]. Therefore, antidiarrhea and antisecretory effects of $Z$. scabra could be due to the presence of these phytochemicals. Besides, these effects were proved to be seen in the different models of this study, which suggests that several different constituents of the extract might be involved in different mechanism of actions to produce antidiarrheal and antisecretory effects.

Moreover, the acute toxicity study revealed the safety of the extract at the limit dose of $2000 \mathrm{mg} / \mathrm{kg}$ in mice. At the test dose, mortality and delayed toxicity were not observed in the 14 days post-treatment period. Likewise, death was not recorded during the acute toxicity test. Therefore, based on the findings, the LD50 value of the $80 \%$ methanolic extract of the plant is above $2000 \mathrm{mg} / \mathrm{kg}$. This indicates that the methanolic extract of $Z$. scabra is better tolerated and safe after oral administered.

\section{Conclusion}

The $80 \%$ methanolic leaf extract of Zehineria scabra showed antidiarrheal activity in animal models. Thus, the findings give the experimental basis to understand the traditional claim of the plant. The 100, 200 and 400 $\mathrm{mg} / \mathrm{Kg}$ doses of the plant extract demonstrated significant antidiarrheal and antisecrtory effect and the higher dose, $400 \mathrm{mg} / \mathrm{kg}$, showed superior efficacy relative to the other doses. However, the extract did not affect the gastrointestinal motility at any of the study doses. The plant extract was also found to have optimal safety margin based on the limit test at $2000 \mathrm{mg} / \mathrm{kg}$ dose level acute toxicity test. Therefore, the plant is potentially useful to develop plant based products after further studies to identify the active principle and the mechanism of action.

\section{Competing interests}

The authors declare that they have no competing interests.

\section{Authors' contributions}

WT and AEH designed and wrote the study proposal. WT, AF and AEG conducted the antidiarrheal and antisecretory tests and phytochemical tests. WT and AEH processed data entry, the statistical analysis and draft manuscript. All authors approved the submitted version of the manuscript.

\section{Acknowledgements}

The authors are grateful to the University of Gondar for funding this study and the Department of Pharmacology of the same University for providing laboratory facility. The authors would like to appreciate the technical support of Mr. Zemene Demelash during the laboratory procedures.

\section{Author details}

${ }^{1}$ Department of Pharmacology and Clinical Pharmacy, School of Pharmacy, Addis Ababa University, Addis Ababa, Ethiopia. ${ }^{2}$ Unit of Pharmacognosy, School of Pharmacy, University of Gondar, Gondar, Ethiopia. ${ }^{3}$ School of Veterinary Medicine, Hawassa University, Hawassa, Ethiopia.

Received: 19 April 2014 Accepted: 27 November 2014 Published: 2 December 2014

\section{References}

1. Meite S, N'guessan DJ, Bahi C, Yapi FH, Djaman AJ, Guede Guina F: Antidiarrheal activity of the ethyl acetate extract of morinda morindoides in rats. Tropical Journal of Pharmaceutical Research 2009, 8(Suppl 3):201-207.

2. Walker CLF, Friberg IK, Binkin N, Young M, Walker N, Fontaine O, Weissman E, Gupta A, Black RE: Scaling up diarrhea prevention and treatment interventions: a lives saved tool analysis. PLoS Med 2011, 8(Suppl 3):e1000428.

3. Palombo EA: Phytochemicals from traditional medicinal plants used in the treatment of diarrhoea: modes of action and effects on intestinal function. Phytother Res 2006, 20(Suppl 9):717-724.

4. World Health Organization: Water and Sanitation. Geneva, Switzerland: WHO; 1996. Volume 12

5. Gutiérrez SP, Sanchez MAZ, Gonzlalez CP, Garcia LA: Antidiarrhoeal activity of different plants used in traditional medicine. Afr J Biotechnol 2007, 6(Suppl 25):2988-2994.

6. Thankurta P, Bhowmik P, Mukjerjee S, Hajra T, Patra A, Bag P: Antibacterial, antisecretory and antihemorrhagic activity of Azadirachta indica used to treat cholera and diarrhea in India. J Ethnopharmacol 2007, 111(Suppl 3):607-612.

7. Syder JD, Merson MH: The magnitude of the global problems of acute diarrheal disease: a review of active surveillance data. Bulletin of the WHO 1982, 60:605-613. 
8. Agunu A, Ahmadu AA, Afolabi SO, Yaro AU, Ehinmidu JO, Mohammed Z Evaluation of the antibacterial and antidiarrhoeal activities of Heeria insignis O. Ktze. Indian J Pharm Sci 2011, 73(Suppl 3):328-332.

9. Messele B, Gebremariam T, Abdel-Mohsen GM: Studies on Extracts of Some Medicinal Plants Traditionally Used for Dermatological Disorders in Ethiopia. Addis Ababa: Addis Ababa University press; 2004

10. Gedif $\mathrm{T}, \mathrm{Hahn} \mathrm{H}$ : The use of medicinal plants in self-care in rural central Ethiopia. J Ethnopharmacol 2003, 87:155-161.

11. Woldegerima B, Gebre-Mariam T, Gedif T: Ethnopharmacological and Pharmaceutical Studies of Medicinal Plants in Dabat District, North Western Ethiopia. Addis Ababa: Addis Ababa University press; 2004.

12. Desta B: Ethiopian traditional herbal drugs. Part II: antimicrobial activity of 63 medicinal plants. J Ethnopharmacol 1993, 39(Suppl 2):129-139.

13. Abew B, Sahile S, Moges F: In vitro antibacterial activity of leaf extracts of Zehneria scabra and Ricinus communis against Escherichia coli and methicillin resistance Staphylococcus aureus. Asian Pac J Trop Biomed 2014, 4(Supp 10):816-820

14. Anand SP, Jeyachandran R, Nandagopalan V: NMR spectral analysis on root extract of zehneria scabra - a vital medicinal climber. J Pharm Sci Res 2011, 3(Suppl 1):1015-1018.

15. Institute of Laboratory Animal Resources: Guide for the Care and use of Laboratory Animals. 7th edition. Washington DC: National Academy Press; 1996.

16. OECD: Guidelines for the Testing of Chemicals; Acute Oral Toxicity: Up-and-Down Procedures. OECD Publishing; 2008. http://www.oecdilibrary. org/environment/test-no-425-acute-oral-toxicity-up-and-downprocedure 9789264071049-en, No 425, Adopted October 2008. DOl:10.1787/20745788.

17. Trease GE, Evans WC: A Textbook of Pharmacognocy. London: Bailliere Tindall Ltd; 1989.

18. Sofowora A: Medicinal Plants and Traditional Medicine in Africa. Ibadan, Nigeria: Spectrum Books; 1993.

19. Franca CS, Menezes FS, Costa LCB, Niculau ES, Alves PB, Pinto JE, Marcal RM: Analgesic and antidiarrheal properties of Ocimum selloi essential oil in mice. Fitoterapia 2008, 79(Suppl 7-8):569-573.

20. Abu Mohammed TI, Muhammad EU, Asharf UC, Mominur R, Razibul H, Atiar R: In vivo antidiarrheal and cytotoxic potential of different fractions of Pandanus Foetidus leaves. Am J Biomed Sci 2013, 5(Suppl 3):208-216.

21. Aye-Than JH, Kukarni W, Tha SJ: Antidiarrheal efficacy of some Burmese indigenous drug formulations in experimental diarrhea models. J Crude Drug Res 1989, 27:195-200.

22. Fewtrell L, Kaufmann RB, Kay D, Enanoria W, Haller L, Colford JM Jr: Water, sanitation, and hygiene interventions to reduce diarrhoea in less developed countries: a systematic review and meta-analysis. Lancet Infect Dis 2005, 5(Suppl 1):42-52.

23. Gutiérrez SP, Mendoz DZ, Munive AH, Martínez AM, González CP, Mendoza ES: Antidiarrheal activity of 19-deoxyicetexone isolated from Salvia ballotiflora Benth in mice and rats. Molecules 2013, 18:8895-8905.

24. Abate G: Etse Debdabe: Ethiopian Traditional Medicine. Addis Ababa: Addis Ababa University press; 1989.

25. Dawit A, Aberra G, Asfaw D, Zewdneh M, Frehiowt A, Fehiwot T, Tesfaye K, Kelbessa U, Kidist Y, Tekele B, Bisrat H, Mulugeta G: Screening of some medicinal plants of Ethiopia for their anti-microbial properties and chemical profiles. J Ethnopharmacol 2005, 97:421-427.

26. Agbor GA, Léopold T, Jeanne NY: The antidiarrhoeal activity of Alchornea cordifolia leaf extract. Phytother Res 2004, 18:873-876.

27. Besra SE, Gomes A, Chaudhury L, Vedasiromoni JR, Ganguly DK: Antidiarrheal activity of seed extract of Albizzia lebbek Benth. Phytother Res 2002, 16:529-533.

28. Brijesh S, Daswani P, Tetali P, Antia N, Birdi T: Studies on the antidiarrhoeal activity of Aegle marmelos unripe fruit: Validating its traditional usage. BMC Complement Altern Med 2009, 9(Suppl 47):1-12.

29. Rouf ASS, Islam MS, Rahman MT: Evaluation of antidiarrheal activity Rumex maritimus root. J Ethnopharmacol 2003, 84:307-310.

30. Chitime HR: Studies on antidiarrheal activity of Calotropis gigantean R.H. in experimental animals. J Phar Pharmaceu Sci 2004, 7(Suppl 1):70-75.

31. Gurgel LA, Silva RM, Santos FA, Martins DTO, Mattos PO, Rao VSN: Studies on the antidiarrheal effect of dragon's blood from Croton urucarana. Phytother Res 2001, 15:319-322.
32. Njinga NS, Sule MI, Pateh UU, Hassan HS, Usman MA, Haruna MS: Phytochemical and antidiarrhea activity of the Methanolic Extract of the Stem Bark of Lannea kerstingii Engl. and K. Krause (Anacardiaceae). J Nat Prod Plant Resour 2013, 3(Suppl 3):43-47.

33. Macauder PJ: Flavonoids affect acetylcholine, prostaglandin $E$ and antigen mediated muscle contration. Prog Clin Biol Res 1986, 231:489-492.

34. Carlo DC, Mascolo N, Izzo AA, Capasso F: Effects of quercetin on the gastrointestinal tract in rats and mice. Phytother Res 1994, 8:42-45.

35. Daswani PD, Brijesh S, Tetali P, Antia NH, Birdi TJ: Antidiarrhoeal activity of Zingiber officinale (Rosc.). Curr Sci 2010, 98(Suppl 2):222-229.

doi:10.1186/1472-6882-14-460

Cite this article as: Tadesse et al:: Experimental assessment of antidiarrheal and antisecretory activity of $80 \%$ methanolic leaf extract of Zehneria scabra in mice. BMC Complementary and Alternative Medicine 2014 14:460.

\section{Submit your next manuscript to BioMed Central and take full advantage of:}

- Convenient online submission

- Thorough peer review

- No space constraints or color figure charges

- Immediate publication on acceptance

- Inclusion in PubMed, CAS, Scopus and Google Scholar

- Research which is freely available for redistribution

Submit your manuscript at www.biomedcentral.com/submit
C BioMed Central 